\title{
Modelling LAI at a regional scale with ISBA-A-gs: comparison with satellite-derived LAI over southwestern France
}

\author{
A. Brut ${ }^{1, *}$, C. Rüdiger ${ }^{1, * *}$, S. Lafont ${ }^{1,2}$, J.-L. Roujean ${ }^{1}$, J.-C. Calvet ${ }^{1}$, L. Jarlan ${ }^{1, *}$, A.-L. Gibelin ${ }^{1}$, C. Albergel ${ }^{1}$, \\ P. Le Moigne ${ }^{1}$, J.-F. Soussana ${ }^{3}$, K. Klumpp ${ }^{3}$, D. Guyon ${ }^{4}$, J.-P. Wigneron ${ }^{4}$, and E. Ceschia ${ }^{5}$ \\ ${ }^{1}$ CNRM/GAME (Météo-France, CNRS), Toulouse, France \\ ${ }^{2}$ LSCE (CEA, CNRS), Gif-sur-Yvette, France \\ ${ }^{3}$ Unité de Recherche sur l'Ecosystème Prairial (INRA), Clermont-Ferrand, France \\ ${ }^{4}$ Unité de recherche Ecologie fonctionnelle et Physique de l'Environnement (INRA), Villenave d'Ornon, France \\ ${ }^{5}$ CESBIO (UPS, CNRS, IRD, CNES), Toulouse, France \\ *now at: CESBIO (UPS, CNRS, IRD, CNES), Toulouse, France \\ *** now at: Department of Civil and Environmental Engineering, The University of Melbourne, Melbourne, Australia
}

Received: 6 February 2009 - Published in Biogeosciences Discuss.: 8 April 2009

Revised: 27 July 2009 - Accepted: 28 July 2009 - Published: 5 August 2009

\begin{abstract}
A} \mathrm{CO}_{2}$-responsive land surface model (the ISBAA-gs model of Météo-France) is used to simulate photosynthesis and Leaf Area Index (LAI) in southwestern France for a 3-year period (2001-2003). A domain of about $170000 \mathrm{~km}^{2}$ is covered at a spatial resolution of $8 \mathrm{~km}$. The capability of ISBA-A-gs to reproduce the seasonal and the interannual variability of LAI at a regional scale, is assessed with satellite-derived LAI products. One originates from the CYCLOPES programme using SPOT/VEGETATION data, and two products are based on MODIS data. The comparison reveals discrepancies between the satellite LAI estimates and between satellite and simulated LAI values, both in their intensity and in the timing of the leaf onset. The model simulates higher LAI values for the C3 crops than the satellite observations, which may be due to a saturation effect within the satellite signal or to uncertainties in model parameters. The simulated leaf onset presents a significant delay for $\mathrm{C} 3$ crops and mountainous grasslands. In-situ observations at a mid-altitude grassland site show that the generic temperature response of photosynthesis used in the model is not appropriate for plants adapted to the cold climatic conditions of the mountainous areas. This study demonstrates the potential of LAI remote sensing products for identifying and locating models' shortcomings at a regional scale.
\end{abstract}

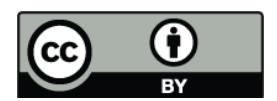

Correspondence to: J.-C. Calvet (calvet@meteo.fr)

\section{Introduction}

Vegetation has a strong impact on the exchange of energy, water and carbon between the land surface and the atmosphere. In particular, it influences the uptake and release of carbon dioxide from and to the atmosphere through photosynthesis and respiration. In addition, the plant growth is governed by the climate. Improving the modelling of the land surface physiological processes is required to provide quantitative estimates of the surface fluxes for meteorological, hydrological and climate applications.

Sensitivity and impact studies using state-of-the-art climate models have shown the importance of the vegetationclimate feedback (Dickinson et al., 1991; Garratt, 1993). Soil-vegetation-atmosphere transfer (SVAT) models were originally designed to simulate exchanges of matter and energy between the surface and the atmosphere, with vegetation leaf area index (LAI) as a forcing variable, rather than a prognostic state. A number of models have recently evolved to include biogeochemical processes (Foley et al., 1996; Sellers et al., 1996a; Calvet et al., 1998; Pitman, 2003), in order to improve the representation of the dynamical behaviour of the vegetation. In such models, the active biomass is often represented by the amount of leaf surface area per unit ground area, expressed through LAI. In most models, LAI represents the one-sided green leaf area of vascular plants and is a key component of the canopy conductance to $\mathrm{CO}_{2}$ and water vapour, and of the carbon and water exchanges. It must be noted that satellite greenness sees more than LAI,

Published by Copernicus Publications on behalf of the European Geosciences Union. 
namely also non-vascular plant green surface, other organs than leaves, and dead brown matter.

Land surface models have served to investigate the role of terrestrial vegetation on climate in regions of the globe where surface-atmosphere feedbacks are strong. Shukla and Mintz (1982) have shown by means of numerical simulations that the evapotranspiration of vegetation widely impacts the global fields of rainfall and air temperature. Zeng and Neelin (2000) investigated the role of the vegetationclimate interaction in African savannah to reach the conclusion that the inter-annual climate variability plays a key role in the maintenance of savannah regions. Alessandri et al. (2007) showed that the introduction of interactive LAI in a global climate model may have a strong impact on the simulations and that the used land surface model must be carefully assessed, in particular its response to climate variables (e.g. air temperature).

The land surface model ISBA-A-gs has proven to be a useful tool to investigate such environmental biophysical factors (Calvet et al., 1998, 2004, 2008). ISBA-A-gs is a $\mathrm{CO}_{2}$ responsive model, which accounts for the vegetation assimilation of $\mathrm{CO}_{2}$. It is able to simulate energy, $\mathrm{CO}_{2}$ and water vapour fluxes at the surface-atmosphere interface. Gibelin et al. (2006) evaluated the model performances at a global scale in the context of climatologic simulations, using atmospheric forcing fields from Numerical Weather Prediction (NWP) reanalyses and observations at a 1 degree resolution. They compared 10 years of simulation of LAI with three satellite-derived LAI datasets. It was found that the ISBAA-gs model is able to capture the general patterns of LAI observed from space and that the simulations fall within the range of variability of satellite-retrieved LAI. Moreover, the same authors highlighted the good agreement of the spatial patterns along the vegetation growing season, between simulated and satellite-derived LAI values, despite some discrepancies in the determination of the leaf onset.

While ISBA-A-gs proved to perform well at the global scale, with aggregated low-resolution LAI products, the use of the model at higher spatial resolution (e.g. for hydrological or vegetation monitoring applications) needs to be assessed. The present work is an attempt to assess the performance of the ISBA-A-gs model at the regional scale, at a relatively high spatial resolution $(8 \mathrm{~km})$. At this scale, as well as at coarser scales, different types of vegetation (crops, forests, grasslands) can be found in a model grid cell and the sub-grid heterogeneity has to be represented. A tile approach is used and for a given grid cell, the model is run for each vegetation type found in the grid-cell. This study is undertaken for a regional watershed, the Adour-Garonne basin located in southwestern France, which was considered in the framework of the CarboEurope Regional Experiment Strategy (CERES) campaign (Dolman et al., 2006).

Satellite data available over time periods of several years provide consistent information to assess the reliability of a land surface model and its representation of the seasonal and inter-annual variability of the vegetation biomass. In the present study, two satellite data sets are considered: (i) the Moderate Resolution Imaging Spectroradiometer (MODIS) Bi-directional Reflectance Distribution Function (BRDF) (Jin et al., 2003), (ii) the SPOT/VEGETATION LAI (Weiss et al., 2007). The considered period of time covers the three annual cycles 2001 to 2003, which present contrasted climatic conditions. For instance, the year 2001 over France corresponded to a standard year in terms of climate, whereas the summer of 2002 was relatively wet. In 2003, the spring and summer periods were anomalously dry, as in many regions of Western Europe (Ciais et al., 2005).

The structure of this paper is as follows: first, the studied region is described, together with the model, the atmospheric forcing and the land cover database. Then, the MODIS reflectance values and the SPOT/VEGETATION observations are presented. In-situ data used to assess the model performance for the case of mid-altitude grasslands, crops and forests, are presented. This is followed by a section dedicated to the comparison of the LAI simulations of ISBA-A-gs with the satellite-derived LAI estimates over southwestern France, which includes a discussion on the seasonal and inter-annual variability of the vegetation. Finally, the paper concludes with a discussion about the use of satellite LAI products, the model performance and shortcomings. Some issues are discussed that deserve attention for future model development and validation.

\section{Model implementation}

\subsection{The ISBA-A-gs model}

The ISBA model (Interactions between Soil, Biosphere and Atmosphere) (Noilhan and Planton, 1989; Noilhan and Mahfouf, 1996) is a land surface model designed to calculate the exchanges of water and energy between the land surface and the atmosphere, for use in numerical weather prediction models and climate models. $\mathrm{A} \mathrm{CO}_{2}$-responsive version of ISBA, called ISBA-A-gs (Calvet et al., 1998; Calvet and Soussana, 2001; Gibelin et al., 2006), allows accounting for the effect of the atmospheric carbon dioxide concentration and the interactions between all environmental factors on the stomatal aperture. ISBA-A-gs also calculates the two main carbon fluxes between the land surface and the atmosphere (i.e. gross primary production (GPP) and total ecosystem respiration). Optionally, ISBA-A-gs calculates the green LAI.

The model has undergone substantial modifications to account for soil moisture stress effects (Calvet, 2000; Calvet et al., 2004) and to include nitrogen dilution (Calvet and Soussana, 2001; Gibelin et al., 2006). Two distinct responses to water stress are currently parameterized in the model: for moderate soil water stress, some plants develop higher values of the water use efficiency $\left(W_{U E}\right)$ following a droughtavoiding strategy, while others show little change or even a 
decrease in $W_{U E}$, corresponding to a drought-tolerant strategy. Moreover, the plant nitrogen content affects the ratio between the total leaf biomass and $\mathrm{LAI}\left(\alpha_{B}\right.$, in $\left.\mathrm{kg} \mathrm{m}^{-2}\right)$. The $\alpha_{B}$ ratio is calculated as a function of plasticity parameters ( $e$ and $f$ ), and of the leaf nitrogen concentration $N_{L}$ (Gibelin et al., 2006). Standard values of the vegetation parameters of the model depend on the biome type and are summarized in Table 1. They were inferred from values determined by a meta-analysis of the literature, sensitivity tests performed at the global scale (Gibelin et al., 2006), and from values used by previous local studies over southwestern France (Rivalland et al., 2005; De Rosnay et al., 2006; Sabater et al., 2007). The southwest region of France is also the area retained in the present study (Fig. 1).

The spatial heterogeneity within a grid cell is represented by tiles (Fig. 2). Within the vegetation tile, each land cover class corresponds to a combination of 12 generic surface types or patches (bare soils, rocks, permanent snow and ice, deciduous broadleaf trees, evergreen broadleaf trees, coniferous trees, C3 crops, C4 crops, irrigated crops, C3 natural herbaceous vegetation, $\mathrm{C} 4$ natural herbaceous vegetation, wetlands). ISBA-A-gs simulates the aggregation of the different patches in the vegetation tile. The simulated LAI shown in this study is always the average LAI of different vegetation types weighted by the fraction of area they cover.

The version of ISBA-A-gs used in this study is imbedded into SURFEX (SURFace Externalisée, Martin et al., 2007), the modelling platform of Météo-France. SURFEX includes a description of soil and vegetation processes. It can be used offline, forced by atmospheric analyses (or by local meteorological observations), or online, coupled with an atmospheric model. In this study, SURFEX is used offline and there is no feedback from the surface to the atmosphere. SURFEX is used for research and operational applications. Several options of the land surface model are available (e.g. one - this study - or several soil layers). ISBA-A-gs is one option of the model. When ISBA-A-gs is used, the interactive vegetation capacity may be activated or deactivated. So far, the ISBAA-gs option was used for research applications, either offline (e.g. Gibelin et al., 2006) or online (e.g. Sarrat et al., 2009). For online applications, the simulations of the coupled model last a few days, at most, and the interactive vegetation is deactivated (LAI values are prescribed). The latest version of ISBA-A-gs in SURFEX (version 1) was used. It includes the possibility to prescribe a crop emergence date and (optionally) to simulate irrigation for summer crops, i.e. crops sown in May and growing at summertime. In this study, the representation of seeding and irrigation practices is used for the $\mathrm{C} 4$ crops (maize), only, as maize is the main irrigated crop in the studied region. An irrigation amount of $30 \mathrm{~mm}$ is added to the precipitation forcing each time the simulated extractable soil moisture content (dimensionless) reaches a predefined threshold. This threshold decreases from 0.70 for the first irrigation, to 0.55 for the second, 0.40 for the third, and 0.25 for the following ones (Calvet et al., 2008). The growth of

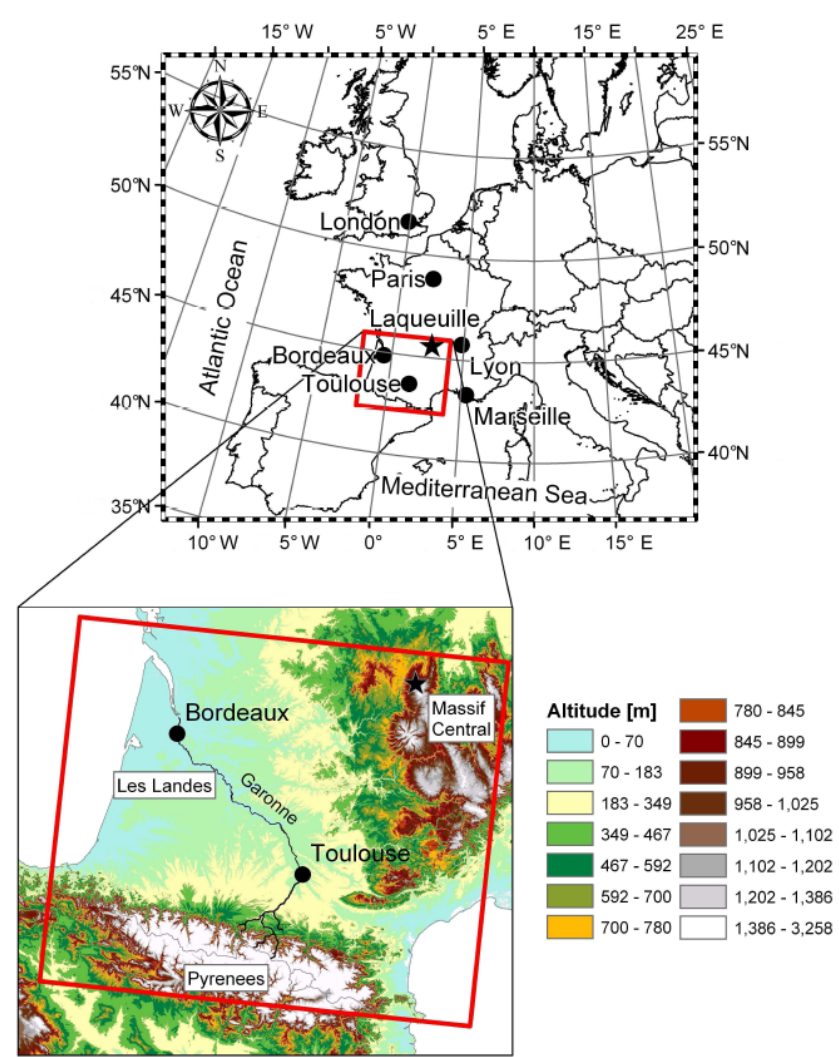

Fig. 1. The study area in southwestern France with its geographic location in Europe (highlighted by the red square). The zoom shows the topography of the study area (obtained from CGIAR CSL, http:// srtm.csi.cgiar.org) and the location of the Laqueuille grassland site.

C3 crops occurs at springtime (i.e. as soon as meteorological conditions become favourable to plant growth) and is simulated like the growth of natural vegetation (no sowing or emergence date has to be prescribed).

\subsection{The soil and land cover databases}

In the SURFEX modelling platform, the soil and surface parameters used by the land surface model are obtained from the ECOCLIMAP global database (Masson et al., 2003). ECOCLIMAP is a database of key surface parameters (soil texture, albedo, emissivity, roughness length, LAI, vegetation fraction, and physiological parameters) for land surface modelling. The land parameters must be spatially consistent and temporally coherent, and are projected onto a grid map in two stages. First, a land cover classification is performed by aggregating the pixel values presenting the closest time series of Normalized Difference Vegetation Index (NDVI) measured by the Advanced Very High Resolution Radiometer (AVHRR) sensor, onboard the NOAA (National Oceanic and Atmospheric Administration) satellite series. The classification is based on climate zones and pre-existing land cover maps. The version of ECOCLIMAP described in Masson et 
Table 1. Values of the ISBA-A-gs parameters for the five vegetation patches used in the simulations over southwestern France. An asterisk shows the values proposed by Gibelin et al. (2006) at the global scale, when they are different.

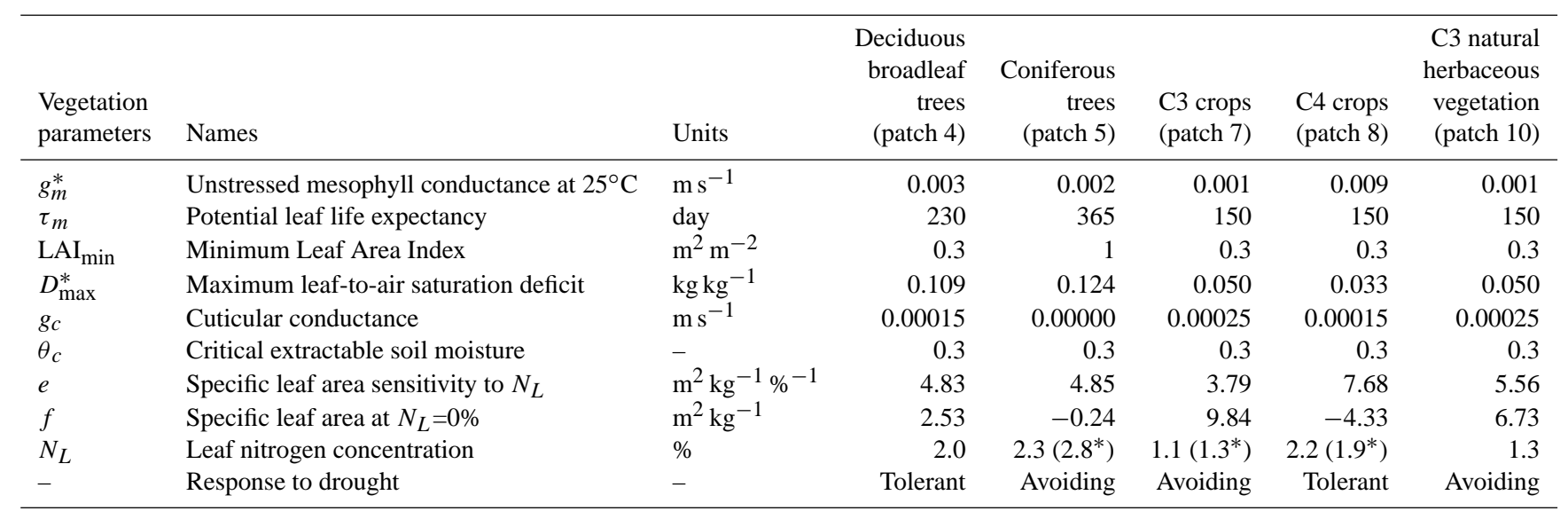

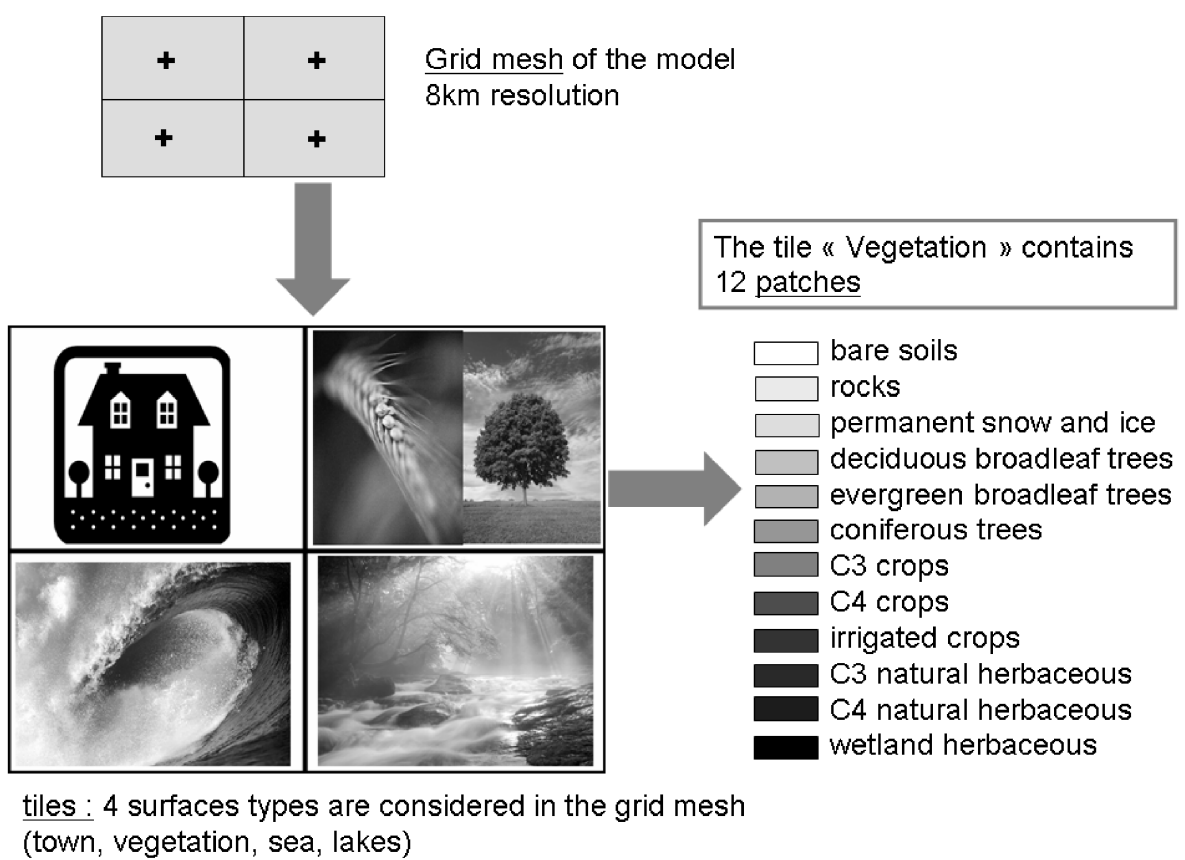

Fig. 2. Sketch of the tile approach considered in SURFEX, the modelling platform including ISBA-A-gs.

al. (2003) consists of 215 ecosystems representing, as much as possible, homogeneous functional vegetation types, at $1 \mathrm{~km}$ resolution. Further, based on the classification nomenclature and look-up tables, a global and monthly database of surface parameters, organized in land cover types, is built.

In this study, a dedicated ECOCLIMAP product was developed for a region of about $170000 \mathrm{~km}^{2}$ in southwestern France. This specific ECOCLIMAP version has 61 ecosystem classes representing a splitting of the initial CORINE land cover database (Heymann et al., 1993), with an enhanced representation of agriculture (more agricultural classes).
More often than not, the ECOCLIMAP classes correspond to a combination of the 6 main patches encountered over southwestern France (i.e. bare soils, coniferous trees, deciduous broadleaf trees, $\mathrm{C} 3$ crops, $\mathrm{C} 4$ crops, $\mathrm{C} 3$ natural herbaceous vegetation). The fraction of those 6 patches is displayed in Fig. 3. The fraction of bare soils is mostly present along the Mediterranean coast. C3 natural herbaceous vegetation is found in mountainous areas (grasslands of Massif Central and throughout the Pyrenees). Deciduous broadleaf trees are distributed throughout the domain except over the Les Landes region, where coniferous trees are dominant. C3 crops are predominantly located in the West and in the East 
of the city of Toulouse, whereas C4 crops are found close to the Garonne river, and in the North and South of the Les Landes forest. The vegetation fraction (veg) corresponds to the percentage of vegetation within a patch. For crops, it is derived from LAI using the simple formula of Kanemasu et al. (1977), veg $=1-\exp (-\alpha \mathrm{LAI})$, with $\alpha=0.6$. For the Les Landes forest, dominated by coniferous trees, the vegetation fraction is set to a constant value of 0.95 . The same value is used for deciduous

broadleaf trees and $\mathrm{C} 3$ natural herbaceous vegetation. The parameter veg is set to 0 for bare soils, rocks and water surfaces.

\subsection{Atmospheric forcing: the SAFRAN database 2001-2003}

The atmospheric forcing data required for simulations over France are provided by the atmospheric analysis system "Système d'Analyse Fournissant des Renseignements A la Neige" (SAFRAN) (Durand et al., 1993, 1999). Initially, it was developed for snow monitoring in mountainous areas. It was extended to the whole of France (Quintana-Seguí et al., 2008) in order to monitor land surface processes (not only snow). SAFRAN produces estimates of meteorological variables and incident radiation fluxes by combining observations and analyses from model outputs. The latter allow the determination of vertical profiles. It uses an optimal interpolation method over climatologically homogeneous areas to build the meteorological fields, in order to ensure a good coherence of the forcing. These areas are of irregular shapes and cover surfaces of usually less than $1000 \mathrm{~km}^{2}$. The initial guess required for the optimal interpolation comes from outputs of the global scale operational NWP model Action Recherche Petite Echelle et Grande Echelle (ARPEGE) of Météo-France (Courtier et al., 1991) and from a re-analysis of the European Center for Meteorological Weather Forecast (ECMWF) model, re-interpolated from a Gaussian grid onto on a regular grid at $0.5^{\circ} \times 0.5^{\circ}$ resolution. The SAFRAN analysis is completed by a number of observations: the analysis of temperature, humidity, wind speed and cloudiness is performed every six hours using observations from the synoptic network. The vertical profiles of these variables are calculated every $300 \mathrm{~m}$. Next, the analysed values are interpolated at hourly time steps. All altitude profiles (temperature, humidity and cloudiness) as well as surface winds are linearly interpolated. Solar and long wave radiation are also calculated, using the radiative transfer scheme of Ritter and Geleyn (1992). The hourly precipitation and phase are estimated by combining the hourly snow-rain transition altitude, the daily rain/snow ratio observations and estimations, and relative humidity. Atmospheric pressure is measured at sea level and then interpolated at each grid point, while accounting for differences in topography.

The SAFRAN database is referenced in the Lambert 2 extended coordinate system at a resolution of $8 \times 8 \mathrm{~km}^{2}$. Over
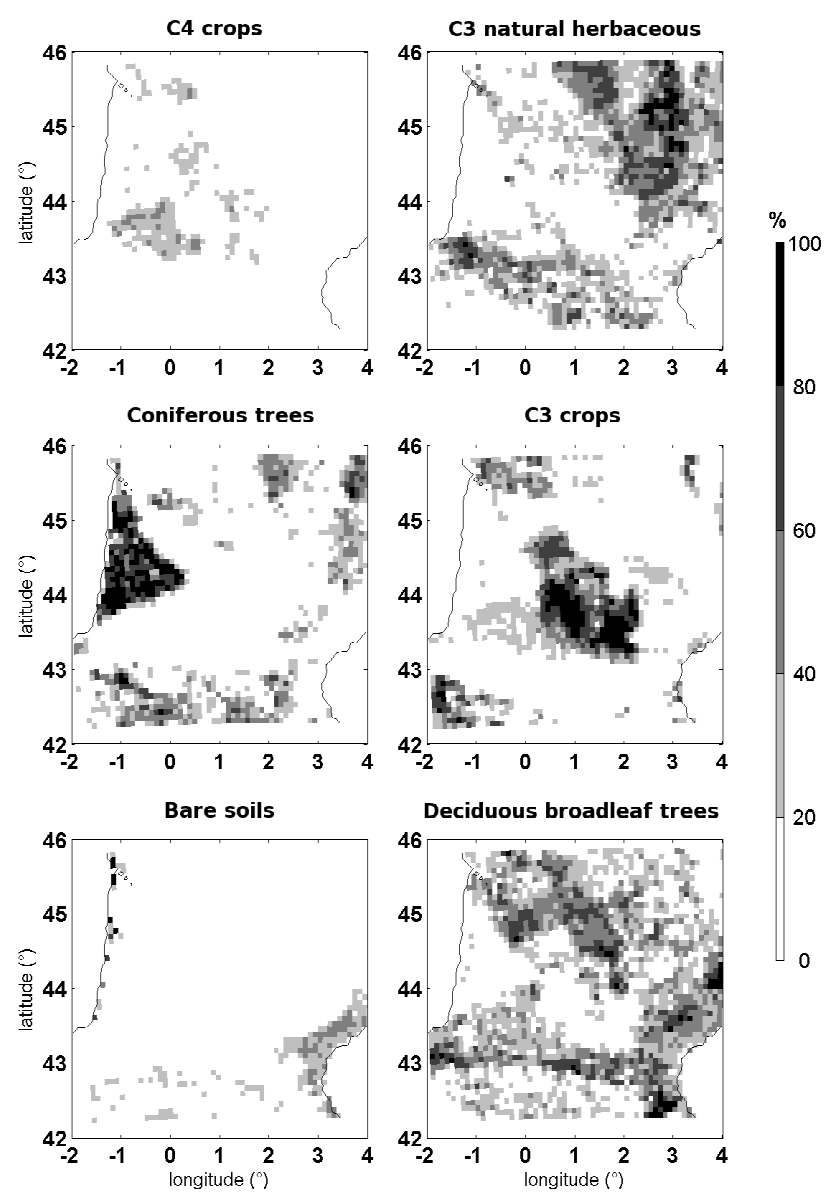

Fig. 3. Percentage of the 6 main patches of ISBA-A-gs in southwestern France (top: C4 crops and C3 natural herbaceous vegetation, middle: coniferous trees and $\mathrm{C} 3$ crops, bottom: bare soils and deciduous broadleaf trees).

the domain considered in this study, the SAFRAN data cover a $51 \times 61$ cell grid. The accuracy of SAFRAN was evaluated by Quintana-Seguí et al. (2008) for the whole of France, who found a reasonable agreement with independent in-situ observations.

\subsection{Simulations}

Simulations covering a 3-year period (2001-2003) were performed with SURFEX for the Adour-Garonne basin in the "offline" mode, i.e. without coupling the land surface with the atmosphere. The chosen region is located between the Atlantic Ocean and the Mediterranean sea and includes the Pyrenees and the Massif Central mountains (Fig. 1). The atmospheric forcing data were obtained from a subset of the SAFRAN database (as described above). The ISBA-A-gs option of SURFEX was run in a configuration able to represent the vegetation growth and the senescence phase, in response to meteorological conditions. In order to initialise the LAI and the soil water content, the model was spun up by 
repeating the simulations over the year 2001. The year 2001 was chosen as the spin-up year, as its general climatic conditions corresponded to average climatic conditions for this region, both in terms of temperature and precipitation. After two cycles, the main variables reached equilibrium conditions. The simulations for the years 2002 and 2003 were then undertaken as open-loop runs. A value of LAI was simulated for each patch present in a given grid cell, and a grid average LAI value was calculated.

\subsection{Leaf onset calculations}

In this study, the leaf onset is defined as the date at which LAI reaches an intermediate value of $\mathrm{LAI}\left(\mathrm{LAI}_{i}\right)$. The difference between this intermediate value and the minimum $\mathrm{LAI}$ value corresponds to $40 \%$ of the amplitude of the seasonal cycle (White et al., 1997; Gibelin et al., 2006). The amplitude of the seasonal cycle is defined as the difference between the maximum and minimum LAI observed over an annual cycle, and $\mathrm{LAI}_{i}=0.4 \mathrm{LAI}_{\max }+0.6 \mathrm{LAI}_{\text {min }}$. This method is robust and well adapted for the comparison of different time series (e.g. the remote sensing products and the model have different sampling times). In this study, this method was applied to both model simulations and satellite LAI observations. As the sampling time of the satellite products is rather coarse (about 10 days), a linear interpolation between two dates is performed in order to retrieve the date at which $\mathrm{LAI}_{i}$ is reached.

\section{Remotely sensed Leaf Area Index}

Two satellite-derived LAI products were used: MODIS and CYCLOPES. They both cover the 2001-2003 period considered in this study.

\subsection{MODIS-based products}

The Moderate Resolution Imaging Spectroradiometer (MODIS; http://modis.gsfc.nasa.gov/) is an instrument on board NASA's Terra and Aqua platforms to collect remote sensing information of the Earth atmosphere, oceans and land surface. Collection 4 of MODIS LAI (Tian et al., 2000) product was analyzed first and was judged too noisy at the $1 \mathrm{~km}$ spatial resolution for the study area even after being class-averaged (see also Garrigues et al., 2008). An alternative was to consider the LAI retrieval method proposed by Roujean and Lacaze (2002), relying on Bi-directional Reflectance Distribution Function (BRDF), and to use the MODIS BRDF/Albedo Level 3 product (MOD43B1). MOD43B1 is a global product at $1 \mathrm{~km}$ spatial resolution, projected onto a sinusoidal grid, and with a 16-day composite time frame.

The algorithm of Roujean and Lacaze (2002) first estimates the fractional cover of vegetation ( $f$ Cover) from a vegetation index, actually the simple difference between visible and near-infrared reflectance interpolated to zenith-nadir observations with the MODIS BRDF model. Then, the effective LAI, $L_{e}$, is retrieved from the formula $f$ Cover $0=A$ $\exp \left(-0.47 L_{e}\right)$. The clumping index (CI) quantifies the level of foliage grouping within distinct canopy structures, such as tree crowns, shrubs, and row crops, relative to a random distribution (Lacaze et al., 2002; Chen et al., 2005). A dynamic retrieval of CI permits to account for mutual leaf shadowing in the sensor field of view. Dividing $L_{e}$ by CI leads to the "true" LAI. For most vegetation canopies, CI is less than 1, which aims at increasing LAI values, from $10 \%$ for grasslands to $30 \%$ for forests, on average.

Below, the reprocessed MODIS LAI product, derived from MOD43B1, is called MODIS-RP. The initial Collection 4 LAI product is called MODIS-INI.

\subsection{CYCLOPES products}

The Carbon Cycle and Change in Land Observational Products from an Ensemble of Satellites (CYCLOPES) project was an initiative aiming at developing and producing global surface parameters from space-borne sensors. In particular, key biophysical parameters (LAI, $f$ APAR and $f$ Cover) were produced for the period 1998-2003 based on the processing of SPOT/VEGETATION data (Baret et al., 2007). Top of canopy reflectance values were corrected for surface directional effects in order to obtain normalized reflectances. A neural network was used to retrieve LAI from the normalized reflectances. The neural network was previously trained from synthetic reflectances produced by the SAIL model (Verhoef, 1985) simulating the radiation transfer within vegetation canopies.

In this study, the Version 3 CYCLOPES LAI product (Postel, 2008) is used. It has a spatial resolution of $1 \mathrm{~km}$ and is based on a temporal composite window of 10 days. The uncertainty of this LAI product is discussed by Garrigues et al. (2008).

\section{In-situ observations}

A local validation of model simulations and remote sensing products is needed. An optimal ground-truthing regional network of phenological observations should be dense, address the main vegetation types, and cover the studied period. Unfortunately, the information available is local, patchy, and infrequent, and the importance of the lack of surface phenological observations has to be stressed out. The available information is described below.

\subsection{Mid-altitude grasslands}

In previous studies, the ISBA-A-gs model was validated over a variety of sites, representing contrasting vegetation types. In southwestern France, different types of crops and forests 
are found, as well as semi-natural mid-altitude grasslands used for extensive grazing. Although C3 natural herbaceous vegetation was simulated by ISBA-A-gs before, at various spatial scales (Gibelin et al., 2006; Sabater et al., 2008), there was no specific representation of the grazed mid-altitude grasslands found in southwestern France. In this study, insitu observations were used to verify the model's performance.

Measurements were made by the Institut National de la Recherche Agronomique (INRA) at an upland semi-natural grassland site $\left(45^{\circ} 38^{\prime} \mathrm{N}, 2^{\circ} 44^{\prime} \mathrm{E}\right.$; $1040 \mathrm{~m}$ a.s.l.) near Laqueuille, Puy de Dôme, France during 2002-2004. The site and the experimental set-up are described in Allard et al. (2007). Meteorological and eddy-covariance $\mathrm{CO}_{2}$ flux measurements were performed. GPP estimates were derived by Allard et al. (2007) from the net ecosystem exchange observations. Two paddocks differing in $\mathrm{N}$ fertilisation and grazing pressure were investigated. In this study, the "extensive" paddock was considered, as it was more representative of the majority of the mid-altitude grasslands found in the mountainous areas of southwestern France (the Pyrenees and Massif Central). LAI observations were performed at the grassland site of Laqueuille in 2002. They are shown in Fig. 7 of Vuichard et al. (2007). The low-fertilized and extensively grazed grassland of Laqueuille grew rapidly in June and reached a maximum LAI of about $2.5 \mathrm{~m}^{2} \mathrm{~m}^{-2}$ at the beginning of July.

\subsection{Crops and forests}

A few field observations of LAI were performed in 2005, close to Toulouse, over crops and forests (Dolman et al., 2006; Jarosz et al., 2009).

In the case of a wheat crop (Lamasquère), maximum LAI was attained at the end of May and the senescence occurred in June. A rapeseed field (Auradé) presented maximum LAI values at the end of April and the senescence occurred in June. A barley field (Montbartier) presented maximum LAI values at the beginning of May and the senescence occurred in May. The maximum LAI of irrigated maize fields (SaintSardos) was attained in July and remained stable till the senescence, which occurred in October. Carbon fluxes and LAI observations at Lamasquère and Auradé are described for a 3-year period (2005-2007) in Béziat et al. (2009).

In the case of a sessile oak forest (the Agre forest), leaf emergence was observed at the end of March. After leaf emergence, LAI increased gradually, and a maximum LAI value was attained in June (at the beginning of June or later, depending where LAI was measured). Over the Les Landes forest (coniferous trees) site of Le Bray, the maximum LAI of the understory and of the trees were observed at the end of June, and at the end of July, respectively. The total LAI of the forest (trees and understory) reached a maximum value of $3.9 \mathrm{~m}^{2} \mathrm{~m}^{-2}$ at the beginning of July.

\section{Comparison of satellite-derived and simulated LAI values}

In this study, the satellite LAI is used as an indirect means to evaluate the vegetation growth component of ISBA-A-gs. Remotely sensed LAI is known to present two drawbacks: (i) it must be corrected for clumping to obtain a true value in agreement with modelled LAI definition; (ii) it saturates at high LAI values (Pontailler et al., 2003). However, the comparison between satellite and modelled LAI is instructive, in particular to assess the ability of the model to represent the seasonal and the inter-annual variability (Gibelin et al., 2006).

Figure 4 displays the 2001-2003 LAI simulated by ISBAA-gs and the satellite-derived datasets (MODIS-RP, MODISIN, CYCLOPES), for the major types of vegetation of southwestern France: coniferous trees, C3 crops, C3 natural herbaceous vegetation and deciduous broadleaf trees. The ISBAA-gs results correspond to mixed patches, and, in this figure, only pixels that contain at least $85 \%$ of the same patch are considered. The number of selected gridpoints for the 4 selected patches is, $62,78,19$, and 23 , respectively. The temporal evolution of LAI for C4 crops is not shown because a modelled pixel dominated by this patch over the study area could not be found. Indeed, the percentage of $\mathrm{C} 4$ crop within a pixel reaches only a maximum value of $45 \%$. Table 2 presents the simulated and satellite-derived leaf onsets and LAI peaks.

The seasonal and inter-annual variability of LAI is driven to a large extent by climate. Figure 5 shows the 2001-2003 average monthly incident shortwave radiation and air temperature at noon, as well as the monthly precipitation for two contrasting climates within the studied area (Fig. 1b): Laqueuille and Toulouse. The climatic conditions of 2001, are representative of the average climate of the region. In 2001, the annual amount of precipitation is about $1200 \mathrm{~mm}$ at Laqueuille, with a maximum in March and April, and about $650 \mathrm{~mm}$ in Toulouse, with a maximum in April and May. Maximum air temperatures vary from $27^{\circ} \mathrm{C}$ in Toulouse and $20^{\circ} \mathrm{C}$ at Laqueuille, in August, to $4^{\circ} \mathrm{C}$ in Toulouse and $-1{ }^{\circ} \mathrm{C}$ at Laqueuille, in December. Figure 5 shows that 2003 was markedly warmer and dryer at both locations. The mean monthly air temperatures are much higher in spring and summer 2003 than in 2001 and 2002. In 2001 and 2002, the area received similar amounts of rainfall, though during different seasons: in 2001, the majority of the precipitation was observed in spring (March, April and May) whereas the main rain events in 2002 occurred later during the summer, thereby supplying the fully developed vegetation with a higher water availability at this time of year.

\subsection{Seasonal variability in $\mathbf{2 0 0 1}$}

In Fig. 4, the MODIS-RP and CYCLOPES satellite-derived LAI present much lower maxima, i.e. present smaller 

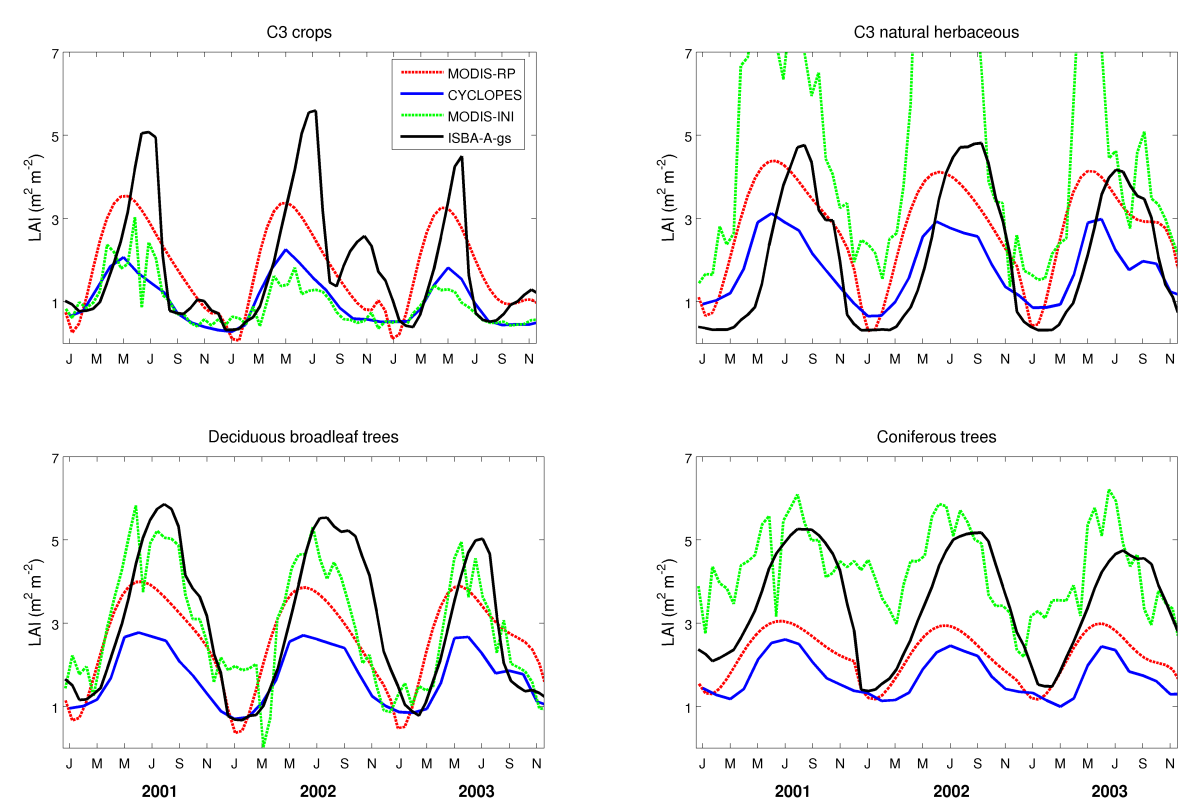

Fig. 4. Evolution of the average LAI for various vegetation patches in southwestern France, between 2001 and 2003 , simulated by the ISBA-A-gs model (black line) and derived from MODIS-RP (red line), MODIS-INI (green line), and CYCLOPES (blue line) products, for pixels containing at least $85 \%$ of the same patch.
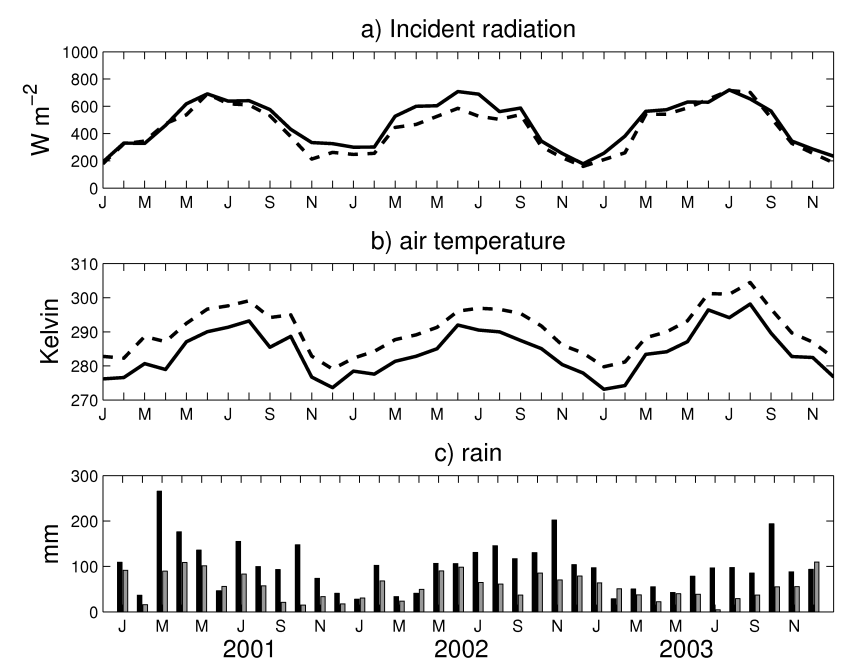

Fig. 5. Mean monthly incident shortwave radiation (a) and air temperature (b) at noon, and monthly precipitation in units of $\mathrm{kg} \mathrm{m}^{-2}$ (c), at the site of Laqueuille, Massif Central (solid lines, dark bars) and in Toulouse (grey dashed line, grey bars), derived from insitu observations and from the SAFRAN database, respectively, between January 2001 and December 2003.

amplitude cycles, than the simulated LAI. The MODIS-INI LAI product is noisy, with a number of spurious low values during the vegetation period. For $\mathrm{C} 3$ crops, the MODIS-INI maximum LAI value is lower than the MODIS-RP product, and the interannual variability is more pronounced. On the other hand, the MODIS-INI maximum LAI values are higher than for MODIS-RP, for the deciduous broadleaf trees, the coniferous trees, and the $\mathrm{C} 3$ natural herbaceous vegetation. The CYCLOPES algorithm produced lower maximum values than those obtained from MODIS-RP. With the exception of $\mathrm{C} 3$ natural herbaceous vegetation, the simulated peak LAI is markedly higher than the MODIS-RP and CYCLOPES peak LAI. Table 2 shows that the difference in peak LAI is particularly large for CYCLOPES (more than $3 \mathrm{~m}^{2} \mathrm{~m}^{-2}$ in the case of $\mathrm{C} 3$ crops and deciduous broadleaf trees). The modelled LAI peak occurs one to two months after the satellite-derived peak.

For the C3 crops, another significant difference between the satellite and simulated LAI is the fast senescence simulated in July. This rapid change in LAI is not reflected in the satellite signal which displays a smooth decrease starting in May, at the end of spring. In this region, the senescence of C3 crops (e.g. wheat) generally occurs in June (see Sect. 4.2) and these crops are harvested in July.

In the case of $\mathrm{C} 3$ natural herbaceous vegetation, the largest discrepancies are found during the first stage of the growing period (the leaf onset). The model and MODIS-RP peak LAI values are consistent, while the CYCLOPES value is much lower, again. The shift of the seasonal cycle is more acute than for $\mathrm{C} 3$ crops. In particular, the peak LAI simulated by ISBA-A-gs presents a delay of more than 2 months. However, the senescence period presents a better agreement. 
Table 2. Average maximum LAI, leaf onset date $\left(d_{o}\right)$, maximum LAI date for various vegetation patches in southwestern France for the period 2001 and 2003, simulated by the ISBA-A-gs model and derived from MODIS (reprocessed and initial Collection 4, "RP" and "INI", respectively) and CYCLOPES products, for $n$ pixels containing at least $85 \%$ of the same patch. For leaf onset, the average value, $<d_{o}>$, is given together with the standard deviation, $\sigma_{d_{o}}$, and the minimum and maximum values, $d_{o N}, d_{o X}:<d_{o}> \pm \sigma_{d_{o}},\left[d_{o N}, d_{o X}\right]$.

\begin{tabular}{|c|c|c|c|c|c|c|c|c|c|c|c|}
\hline \multirow[t]{2}{*}{$\begin{array}{l}\text { Patch } \\
\text { (85\% threshold) }\end{array}$} & \multirow[t]{2}{*}{$n$} & \multirow[t]{2}{*}{ Product } & \multicolumn{3}{|c|}{$\begin{array}{l}\text { Maximum LAI } \\
\qquad\left(\mathrm{m}^{2} \mathrm{~m}^{-2}\right)\end{array}$} & \multicolumn{3}{|c|}{$\begin{array}{l}\text { Leaf onset } \\
\text { (DoY) }\end{array}$} & \multicolumn{3}{|c|}{$\begin{array}{l}\text { Maximum LAI } \\
\quad(\text { DoY })\end{array}$} \\
\hline & & & 2001 & 2002 & 2003 & 2001 & 2002 & 2003 & 2001 & 2002 & 2003 \\
\hline \multirow[t]{4}{*}{$\begin{array}{l}\text { Coniferous_trees } \\
\text { (patch 5) }\end{array}$} & \multirow[t]{4}{*}{62} & ISBA-A-gs & 5.26 & 5.17 & 4.75 & $\begin{array}{r}131 \pm 6.1 \\
{[123,167]}\end{array}$ & $\begin{array}{r}123 \pm 6.2 \\
{[118,162]}\end{array}$ & $\begin{array}{r}123 \pm 3.7 \\
{[119,147]}\end{array}$ & 225 & 273 & 225 \\
\hline & & MODIS_RP & 3.05 & 2.95 & 2.99 & $\begin{array}{l}86 \pm 4.3 \\
{[78,94]}\end{array}$ & $\begin{array}{r}92 \pm 5.7 \\
{[82,103]}\end{array}$ & $\begin{array}{l}89 \pm 5.7 \\
{[74,99]}\end{array}$ & 193 & 193 & 177 \\
\hline & & MODIS_INI & 5.15 & 4.88 & 5.27 & $\begin{array}{r}44 \pm 34.7 \\
{[1,147]}\end{array}$ & $\begin{array}{r}42 \pm 52.3 \\
{[1,152]}\end{array}$ & $\begin{array}{r}74 \pm 52.2 \\
{[6,148]}\end{array}$ & 225 & 177 & 193 \\
\hline & & CYCLOPES & 2.61 & 2.46 & 2.44 & $\begin{array}{r}120 \pm 2.2 \\
{[109,123]}\end{array}$ & $\begin{array}{r}123 \pm 4.4 \\
{[107,129]}\end{array}$ & $\begin{array}{r}120 \pm 2.3 \\
{[109,123]}\end{array}$ & 195 & 195 & 165 \\
\hline \multirow[t]{4}{*}{$\begin{array}{l}\text { C3_crops } \\
\text { (patch 7) }\end{array}$} & \multirow[t]{4}{*}{78} & ISBA-A-gs & 5.08 & 5.59 & 4.50 & $\begin{array}{l}130 \pm 10.4 \\
{[109,150]}\end{array}$ & $\begin{array}{r}128 \pm 6.5 \\
{[113,145]}\end{array}$ & $\begin{array}{r}120 \pm 4.1 \\
{[114,132]}\end{array}$ & 193 & 209 & 177 \\
\hline & & MODIS_RP & 3.54 & 3.37 & 3.26 & $\begin{array}{l}60 \pm 0.6 \\
{[60,62]}\end{array}$ & $\begin{array}{l}64 \pm 0.6 \\
{[63,65]}\end{array}$ & $\begin{array}{l}64 \pm 0.8 \\
{[63,68]}\end{array}$ & 145 & 145 & 129 \\
\hline & & MODIS_INI & 2.22 & 1.62 & 1.30 & $\begin{array}{r}88 \pm 53.4 \\
{[1,200]}\end{array}$ & $\begin{array}{r}70 \pm 39.0 \\
{[0,190]}\end{array}$ & $\begin{array}{l}72 \pm 24.7 \\
{[10,147]}\end{array}$ & 161 & 161 & 145 \\
\hline & & CYCLOPES & 2.07 & 2.26 & 1.82 & $\begin{array}{l}60 \pm 2.9 \\
{[57,72]}\end{array}$ & $\begin{array}{l}71 \pm 1.4 \\
{[70,76]}\end{array}$ & $\begin{array}{l}83 \pm 3.8 \\
{[78,93]}\end{array}$ & 135 & 135 & 135 \\
\hline \multirow[t]{4}{*}{$\begin{array}{l}\text { C3_natural_herbaceous_vegetation } \\
\text { (patch 10) }\end{array}$} & \multirow[t]{4}{*}{19} & ISBA-A-gs & 4.77 & 4.81 & 4.17 & $\begin{array}{r}158 \pm 5.7 \\
{[143,166]}\end{array}$ & $\begin{array}{r}154 \pm 5.7 \\
{[140,161]}\end{array}$ & $\begin{array}{r}140 \pm 6.4 \\
{[120,150]}\end{array}$ & 241 & 273 & 209 \\
\hline & & MODIS_RP & 4.38 & 4.12 & 4.14 & $\begin{array}{l}76 \pm 5.0 \\
{[62,81]}\end{array}$ & $\begin{array}{l}77 \pm 4.9 \\
{[62,82]}\end{array}$ & $\begin{array}{l}71 \pm 4.6 \\
{[59,77]}\end{array}$ & 177 & 177 & 145 \\
\hline & & MODIS_INI & 5.97 & 6.34 & 4.41 & $\begin{array}{r}83 \pm 34.3 \\
{[9,136]}\end{array}$ & $\begin{array}{r}96 \pm 33.5 \\
{[0,148]}\end{array}$ & $\begin{array}{r}130 \pm 60.9 \\
{[12,242]}\end{array}$ & 145 & 161 & 161 \\
\hline & & CYCLOPES & 3.12 & 2.93 & 2.99 & $\begin{array}{l}105 \pm 6.9 \\
{[82,109]}\end{array}$ & $\begin{array}{l}104 \pm 8.0 \\
{[80,110]}\end{array}$ & $\begin{array}{l}107 \pm 3.3 \\
{[97,111]}\end{array}$ & 165 & 165 & 165 \\
\hline \multirow[t]{4}{*}{$\begin{array}{l}\text { Deciduous_broadleaf_trees } \\
\text { (patch 4) }\end{array}$} & \multirow[t]{4}{*}{23} & ISBA-A-gs & 5.86 & 5.53 & 5.03 & $\begin{array}{r}129 \pm 9.3 \\
{[103,138]}\end{array}$ & $\begin{array}{r}132 \pm 8.0 \\
{[119,145]}\end{array}$ & $\begin{array}{l}119 \pm 9.6 \\
{[98,131]}\end{array}$ & 225 & 225 & 209 \\
\hline & & MODIS_RP & 4.00 & 3.86 & 3.88 & $\begin{array}{l}74 \pm 6.2 \\
{[67,84]}\end{array}$ & $\begin{array}{l}75 \pm 5.9 \\
{[68,84]}\end{array}$ & $\begin{array}{l}71 \pm 4.3 \\
{[66,78]}\end{array}$ & 177 & 177 & 161 \\
\hline & & MODIS_INI & 5.09 & 4.66 & 4.14 & $\begin{array}{r}52 \pm 52.0 \\
{[1,149]}\end{array}$ & $\begin{array}{l}70 \pm 47.8 \\
{[17,132]}\end{array}$ & $\begin{array}{r}106 \pm 38.3 \\
{[21,151]}\end{array}$ & 161 & 177 & 161 \\
\hline & & CYCLOPES & 2.78 & 2.71 & 2.67 & $\begin{array}{l}102 \pm 7.2 \\
{[94,112]}\end{array}$ & $\begin{array}{r}98 \pm 7.3 \\
{[90,110]}\end{array}$ & $\begin{array}{r}106 \pm 2.5 \\
{[103,110]}\end{array}$ & 165 & 165 & 165 \\
\hline
\end{tabular}

Concerning the deciduous broadleaf trees and coniferous trees, the modelled LAI is higher, with an offset of 1.8 to $2.2 \mathrm{~m}^{2} \mathrm{~m}^{-2}$ for MODIS-RP and 2.6 to $3.1 \mathrm{~m}^{2} \mathrm{~m}^{-2}$ for CYCLOPES. Contrary to $\mathrm{C} 3$ crops and deciduous broadleaf trees, for coniferous trees, the modelled LAI is always above the MODIS-RP and CYCLOPES observations, even in winter. Moreover, the peak LAI simulated by the model exhibits a delay of about one month compared to the satellite estimates.

Finally, one may notice that the start of vegetation determined with CYCLOPES is in better agreement with the model than from MODIS-RP for C3 natural herbaceous vegetation, coniferous trees and deciduous broadleaf trees. Weiss et al. (2007) suggest that the CYCLOPES products offer a better timing of the phenology of the vegetation than
MODIS-RP data, but underestimate the intensity of LAI (which is in agreement with the observations made in this study).

Figure 6 presents a spatial comparison of the modelled and MODIS-RP LAI at four dates in 2001. The MODIS-RP data are used, only, as they have been corrected for clumping effects. Discrepancies between the LAI simulations (top row of Fig. 6) and the satellite-derived LAI (bottom row of Fig. 6) are discernable. The springtime vegetation growth simulated by ISBA-A-gs (from DoY 33 to DoY 145), is more vigorous along the Atlantic coast and in the Garonne valley. On DoY 33, the highest values of LAI (around $2 \mathrm{~m}^{2} \mathrm{~m}^{-2}$ ) are found in these low altitude areas. The highest LAI value is simulated for the coniferous trees of the Les Landes forest. The simulated springtime vegetation growth is much lower 

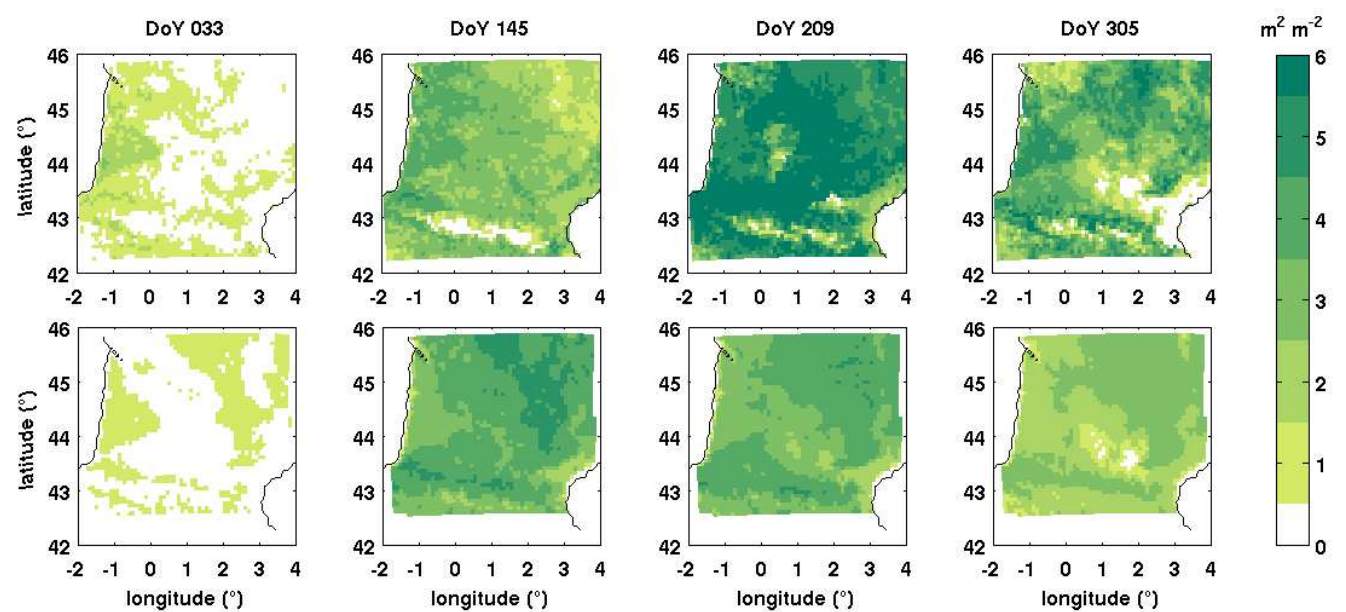

Fig. 6. Leaf area index for four dates in 2001, (top) simulated by ISBA-A-gs and, (bottom) retrieved from MODIS-RP. From left to right: day of year (DoY) 33, 145, 209, 305 (2 February, 25 May, 28 July, 1 November 2001, respectively).

for the mid-altitude $\mathrm{C} 3$ natural herbaceous vegetation of the Pyrenees (except close to the Atlantic coast) and of Massif Central. A contrasting result is obtained with the MODIS-RP LAI for the mid-altitude $\mathrm{C} 3$ natural herbaceous vegetation, as it seems to grow more rapidly than in other areas (Fig. 6). At the end of July (DoY 209), the simulated LAI reaches maximum values (up to $6 \mathrm{~m}^{2} \mathrm{~m}^{-2}$ ) for most regions except for portions of the agricultural areas composed of $\mathrm{C} 3$ crops. For the latter, the senescence is already finished. At the end of October (DoY 305), the C3 crop area around Toulouse and the region along the Mediterranean coast present markedly low LAI values. At that time, the LAI remains high (more than $4 \mathrm{~m}^{2} \mathrm{~m}^{-2}$ ) for deciduous broadleaf trees and coniferous trees, only.

Like Fig. 4, Fig. 6 shows that the modelled plant growth depends on both the climate and the vegetation type. As there are no phenological attributes in ISBA-A-gs, the simulated vegetation growth is driven by the climate. For example, the main driver of the senescence of $\mathrm{C} 3$ crops like wheat, in ISBA-A-gs, is the summer drought. If favourable conditions (e.g. rainfall suppressing the drought) occur at the end of the summer or during the autumn, the model is able to simulate re-growths (Calvet et al., 2008).

Figure 7 presents for 2001 the simulated leaf onset, defined as the date at which LAI reaches an intermediate value of LAI (Sect. 2.5). The leaf onset first starts along the Mediterranean coast and along the Atlantic coast (southeastern and western parts of the domain, respectively). Those regions are less cloudy at springtime, with higher temperatures. To the south of the Les Landes forest and north of Toulouse (i.e. central part of the map), the modelled leaf onset occurs between DoY 120 and DoY 140 whereas over mountainous areas (northeast of the map and Pyrenees), it occurs later, between DoY 140 and DoY 180.

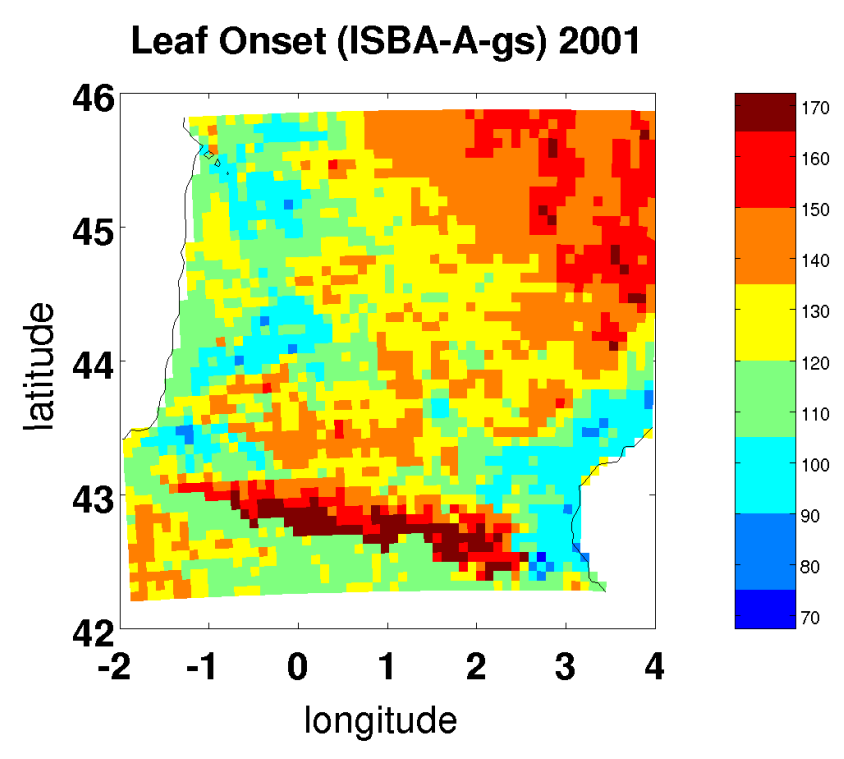

Fig. 7. Leaf onset for the year 2001 estimated with ISBA-A-gs. The scale indicates the day of year (DoY) i.e. the date of growth of the vegetation according to the definition used in Gibelin et al. (2006).

Figure 8 shows the difference between model and satellite leaf onset. The CYCLOPES and MODIS-RP products are considered. The calculation of the leaf onset from the satellite data allows identifying clear patterns, resembling those of the simulations. However, the comparison between the model and the satellite leaf onset shows a temporal shift that varies from one grid cell to another. Figure 8 shows that in 2001, these differences occur, particularly, in the cultivated region in the centre of the study area. Also, the differences with MODIS-RP are very large for the midaltitude C3 natural herbaceous vegetation of the Pyrenees 

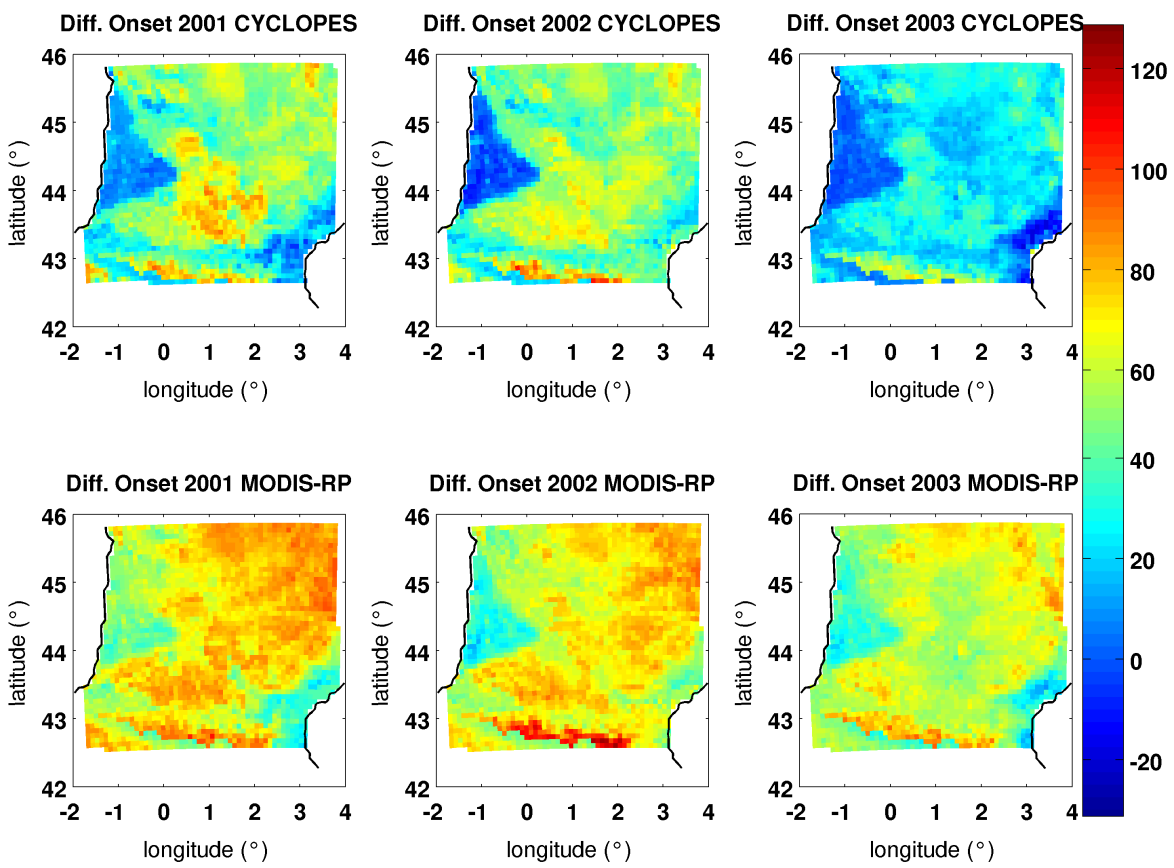

Fig. 8. Differences in leaf onset (days) between the ISBA-A-gs model simulations and (top) CYCLOPES and (bottom) MODIS-RP satellite data for 2001, 2002 and 2003. In most cases, delays in the simulated leaf onset are observed.

and Massif Central. Figure 8 confirms that the leaf onset derived from CYCLOPES agrees better with the modelled leaf onset. There is a general agreement of the spatial distribution of the leaf onset differences of MODIS-RP and CYCLOPES with ISBA-A-gs. For both products, lower leaf onset differences are observed in the Les Landes area and close to the Mediterranean coast. Also, leaf onset differences are smaller in 2003.

\subsection{Inter-annual variability}

In Sect. 5.1, the 2001 annual cycle was considered in order to verify the simulation of the seasonal cycle. As the behaviour of the model may change from one year to another, three annual cycles are now considered: 2001, 2002, and 2003. While 2001 is climatologically a standard year, 2002 and 2003 are marked by a wet and cool summer, and a very dry and hot spring and summer, respectively (Fig. 5). In 2003, the unusual low amount of precipitation and high temperatures caused an early stress of the vegetation and accelerated the senescence.

Model vs. satellite differences are observed for all the vegetation types, throughout the studied period (Figs. 4 and 8). The model generally simulates a delayed and higher maximum LAI than that estimated with the satellites.

The simulated LAI of $\mathrm{C} 3$ natural herbaceous vegetation reaches about the same maximum values as suggested by the observed data from MODIS-RP but a delay of 2 months is apparent in 2001 and 2003, 3 months in 2002. For the de- ciduous broadleaf trees and for the coniferous trees, the simulated LAI cycle shows a stronger magnitude than the one detected by satellite, with a delay of the annual peak.

For C3 crops, the two contrasting climatic annual cycles of 2002 and 2003 influence the simulated LAI (Fig. 4). In 2003, a low maximum LAI value $\left(\sim 4 \mathrm{~m}^{2} \mathrm{~m}^{-2}\right)$ occurring at the end of June is simulated, whereas the maximum value is higher in 2002 (about $6 \mathrm{~m}^{2} \mathrm{~m}^{-2}$ ) and occurs at the end of July. More realistic dates of peak LAI can be derived from the MODIS-RP and CYCLOPES products, ranging from the second week of May to the end of May. In 2002, ISBA-A-gs simulates two marked peaks within the cycle of $\mathrm{C} 3$ crops: the second peak (a regrowth caused by rainfall events) is simulated in the autumn. In the studied area, intermediate crops (like nitrogen fixing legumes) are not commonly used. In most cases the agricultural fields are left unperturbed after the harvest and natural vegetation growth or crop regrowth may occur. Although the satellite observed a slow decrease of LAI in 2002, neither CYCLOPES nor MODIS-RP detected this marked second maximum. The model seems to have a strong response to the climate variability which is not observed by the satellite products. An explanation could be the difficulty to represent the $\mathrm{C} 3$ crop diversity in the model. However, in 2003, due to a marked summer drought, both simulations and satellite-derived data present a shorter cycle of the plant growth.

For C3 natural herbaceous vegetation and deciduous broadleaf trees, the modelled and observed vegetation cycles 
in 2001 and 2002 are similar. In 2003, the satellite-derived LAI (MODIS-RP, CYCLOPES), presents a weak regrowth at the end of August or in September. This is consistent with the moderate regrowth simulated at the end of August. For deciduous broadleaf trees, the drought of 2003 induces a decrease of the simulated LAI in July, which is observed, to some extent, by MODIS-RP and CYCLOPES.

\subsection{Discussion about the leaf onset}

The discrepancy between the satellite and modelled LAI, and the large differences in leaf onset may be attributed to the shortcomings of either model or satellite LAI products, or both. Figure 8 and Table 2 show that on average, the modelled leaf onset occurs later than the satellite leaf onset, for all vegetation types. The best agreement is found for C3 natural herbaceous vegetation and deciduous broadleaf trees along the northern border of the Pyrenees, and for the Les Landes forest (mainly composed of coniferous trees). For MODIS-RP, the difference in leaf onset is particularly acute for the mid-altitude $\mathrm{C} 3$ natural herbaceous vegetation of Massif Central (north-east of the domain). For CYCLOPES, the largest differences are observed for $\mathrm{C} 3$ crops.

For all the vegetation types and for both MODIS-RP and CYCLOPES, the differences vary from one year to another. The median difference in leaf onset (and standard deviation) are $72 \pm 2.8$ day, $67 \pm 3.8$ day, and $58 \pm 2.8$ day, for 2001, 2002, and 2003, respectively, for MODIS-RP, and $50 \pm 4.7$ day, $48 \pm 5.5$ day, and $25 \pm 3.8$ day, for 2001, 2002, and 2003, respectively, for CYCLOPES. The lowest median difference is observed for 2003, with the most marked summer drought.

The very high variability of leaf onset dates presented in Table 2 for MODIS-INI (standard deviations ranging from 24 to 60 days) confirms the difficulty in using this product.

\subsubsection{Uncertainties in satellite products}

A surprising result is that the onset of vegetation given by CYCLOPES may significantly differ from MODIS-RP (Table 2).

Several sources of uncertainty in the satellite LAI products have to be considered (Garrigues et al., 2008):

- the inability of the satellite products to represent the high LAI values observed at the end of the growing season (the saturation effect). The saturation effect tends to level out the last phase of the vegetation growth period, and to produce an apparently earlier calculated leaf onset. The lower discrepancy between the modelled and the satellite-derived leaf onset in 2003 may be due to the lower peak LAI values reached during this wet year, decreasing the saturation effect;

- while the model simulates a green LAI, the satellitederived LAI is influenced by all the vegetation elements (including, e.g. dead leaves) and the senescence as seen from space may occur later than in the real world. This effect accentuates the misrepresentation, in the satellite LAI products, of the last phase of the vegetation growth.

\subsubsection{Uncertainties in model simulations}

While for the mid-altitude $\mathrm{C} 3$ natural herbaceous vegetation and for $\mathrm{C} 3$ crops the satellite LAI products permit to identify a shortcoming of the model, it is difficult to conclude for other model's grid cells presenting a less pronounced difference in leaf onset.

Several sources of uncertainty in the simulated LAI have to be considered:

- The plant-extractable water capacity of soils and the plant rooting depth used in the model are quite uncertain parameters. In the functional approach used in ISBAA-gs, these parameters influence the plant response to drought and the date at which the simulated maximum LAI is reached. Calvet et al. (2008) have shown that the parameters used in ISBA-A-gs for C3 crops permit to simulate realistic LAI and biomass values for wheat in southwestern France. In this study, the maximum extractable soil moisture of low vegetation varies with soil texture and reaches $135 \mathrm{~kg} \mathrm{~m}^{-2}$, against $124 \mathrm{~kg} \mathrm{~m}^{-2}$ used by Calvet et al. (2008) for wheat. A sensitivity analysis of the model (not shown), indicates that overestimating the maximum extractable soil moisture increases the length of the growing period and delays the maximum LAI and the leaf onset.

- The parameters used for $\mathrm{C} 3$ crops permit to represent wheat (Calvet et al., 2008), but other C3 crops are present in the studied region and contribute to the satellite observations. The difficulty to represent the land surface heterogeneity in a land surface model, the agricultural practices, and to account for the presence of several C 3 crops other than wheat (e.g. barley, rapeseed, in southwestern France), with different growing cycles, is a source of uncertainty. Generally, ISBA-A-gs has difficulties in representing the earliest leaf onsets (e.g. those observed for barley and rapeseed). Working on model parameters could help solve this problem. Then, a specific patch would have to be added in order to represent those early growing crops. Also, a specific patch would be needed to represent $\mathrm{C} 3$ summer crops (e.g. sunflower). Upgrading the model would require a detailed land use map for crops, covering the studied area, based on high-resolution satellite data. Such a land use map has still to be developed.

- A potential source of uncertainty in the simulations of ISBA-A-gs is the temperature response of photosynthesis. In the current version of the model, a uniform optimum temperature of $32^{\circ} \mathrm{C}$ is used, and is too high for 
plants adapted to cold climates like mid-altitude $\mathrm{C} 3$ natural herbaceous vegetation of Massif Central (Gilmanov et al., 2007).

In order to confirm this hypothesis, the daytime simulated GPP of mid-altitude C3 natural herbaceous vegetation was compared to the observations at the Laqueuille site (Sect. 4), as a function of air temperature (Fig. 9). Figure 9a shows that high GPP values are observed between $8^{\circ} \mathrm{C}$ and $23^{\circ} \mathrm{C}$. The observed maximum GPP in Laqueuille is reached at an air temperature value of about $15^{\circ} \mathrm{C}$. This is much less than the optimal temperature of $32^{\circ} \mathrm{C}$ used in the model. While significant GPP levels are observed below $5^{\circ} \mathrm{C}$, no significant vegetation activity is simulated by the model at this temperature and the simulated GPP is very low. These different levels of vegetation activity at low temperatures permit to explain the discrepancy between the observed and the modelled leaf onset. In addition, it seems that mid-altitude grasslands assimilate less carbon in warmer conditions (Allard et al., 2007; Gilmanov et al., 2007). As a consequence, the observed and modelled LAI reach comparable magnitudes but with a time shift.

\section{Conclusions}

This paper presents an evaluation of the vegetation growth component of the ISBA-A-gs land surface model, at a regional scale. The model was implemented in the SURFEX modelling platform of Météo-France and used to represent the vegetation evolution over three years in southwestern France, a heterogeneous area including various agricultural crops, grasslands, deciduous broadleaf tress and coniferous trees. The LAI simulations were compared to three different satellite-based LAI products: LAI estimates were customized from the MODIS BRDF product or derived from the MODIS Collection 4 dataset, and the CYCLOPES V3 LAI product was used. Deriving LAI products from remotely sensed reflectances is still challenging. The difference between the MODIS and CYCLOPES LAI products, as discussed in this study, demonstrates that the retrieval process may be affected by significant uncertainties. The comparison showed large discrepancies both between the satellite products and between satellite and simulated LAI. The satellitederived products present different maximum values of LAI for all the vegetation types. The CYCLOPES LAI was much lower than the MODIS-RP LAI. More often than not, the leaf onset and the date of the peak LAI were different from one LAI estimate to another. Therefore, in most situations, the model-satellite discrepancies could be explained by uncertainties and/or different definitions of LAI. Possible causes of the misrepresentation of the plant phenology by the satellite LAI products were discussed in Sect. 5.3. Signal saturation and the difficulty to extract a green LAI information from satellite observations are to be accounted for. Since the definition of the simulated LAI differs from the satellite LAI,
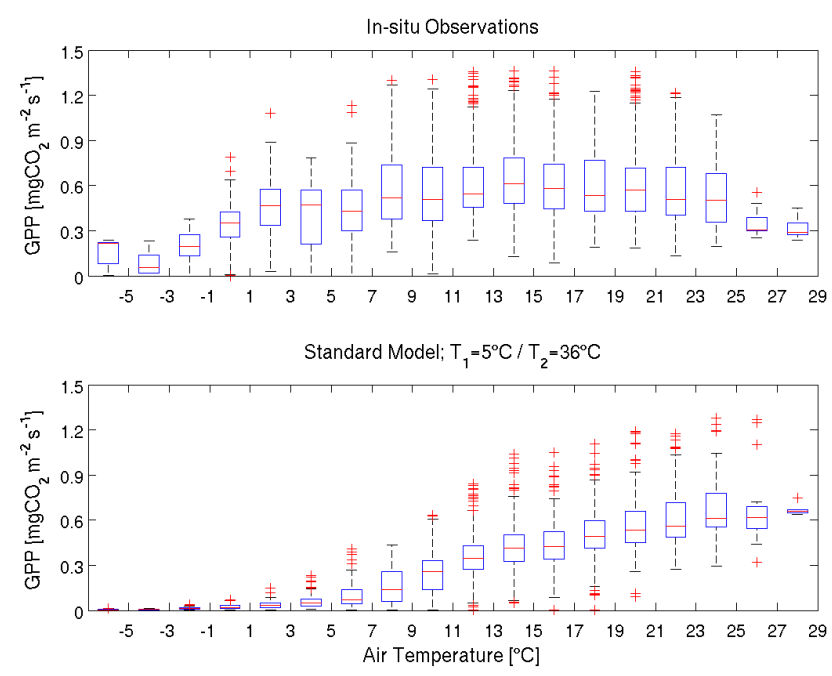

Fig. 9. The gross primary production (GPP) of a mid-altitude grassland versus air temperature (top) measured in-situ at Laqueuille (Massif Central) for the 2004 annual cycle and (bottom) estimated with ISBA-A-gs (with temperature parameters $T_{1}$ and $T_{2}$ as in Calvet (2000) for C3 plants) at the same location and for the same period of time. Binned values are presented: $25-75 \%$ percentiles (blue boxes), median values (red bars), 1.5 times the interquartile range (whiskers), outliers (+).

it can be recommended that observation operators based on the simulated radiative transfer within the vegetation canopy be developed and implemented in the land surface models. Such observation operators would allow the model to mimic the satellite LAI products and reduce the bias between the observations and the simulations. This is a prerequisite for data assimilation (Sabater et al., 2008).

Moreover, this study demonstrated that large differences between the existing satellite LAI products and the ISBA-Ags simulations were a powerful indicator of the main model's shortcomings. The particularly large difference in leaf onset for $\mathrm{C} 3$ natural herbaceous vegetation permitted to identify a weakness of the model (the misrepresentation of the adaptation of the photosynthesis temperature response to cold/mountainous regions), and this was confirmed by in-situ observations at the site of Laqueuille.

Acknowledgements. This study was co-funded by the European Commission within the GMES initiative in FP6 and FP7, in the framework of the geoland and geoland2 integrated GMES projects on land cover and vegetation, by the RTE CYCLOPES project, and by the EOP-SM/1104 ESA project. C. Rüdiger and C. Albergel were supported by CNES post-doctoral and doctoral fellowships. $\mathrm{S}$. Lafont was supported by the CarboFrance project of the GICC programme of the French Ministry of Environment. The authors would like to thank Laurent Franchistéguy and Florence Habets for their help in preparing the meteorological forcing.

Edited by: A. Neftel 


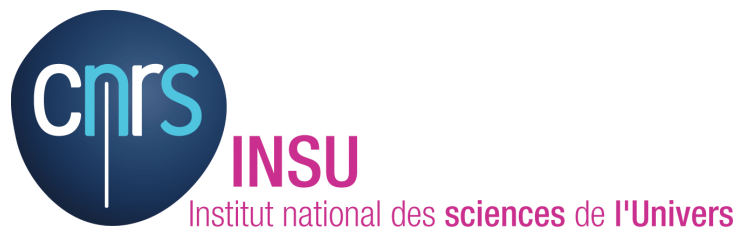

The publication of this article is financed by CNRS-INSU.

\section{References}

Allard, V., Soussana, J.-F., Falcimagne, R., Berbigier, P., Bonnefond, J. M., Ceschia, E., D’hour, P., Hénault, C., Laville, P., Martin, C., and Pinarès-Patino, C.: The role of grazing management for the net biome productivity and greenhouse gas budget $\left(\mathrm{CO}_{2}\right.$, $\mathrm{N}_{2} \mathrm{O}$ and $\mathrm{CH}_{4}$ ) of semi-natural grassland, Agr. Ecosyst. Environ., 121, 47-58, doi:10.1016/j.agee.2006.12.004, 2007.

Alessandri, A., Gualdi, S., Polcher, J., and Navarra, A.: Effects of Land Surface-Vegetation on the Boreal Summer Surface Climate of a GCM, J. Climate, 20(2), 225-278, 2007.

Baret, F., Hagolle, O., Geiger, B., Bicheron, P., Miras, B., Huc, M., Berthelot, B., Niño, F., Weiss, M., Samain, O., Roujean, J.L., and Leroy, M.: LAI, fAPAR and fCover CYCLOPES global products derived from VEGETATION. Part 1: Principles of the algorithm, Remote Sens. Environ., 110, 275-286, 2007.

Béziat, P., Ceschia, E., and Dedieu, G.: Carbon balance of a three crop succession over two cropland sites in South West France, Agr. Forest Meteorol., 149, 1628-1645, 2009.

Calvet, J.-C., Noilhan, J., Roujean, J.-L., Bessemoulin, P., Cabelguenne, M., Olioso, A., and Wigneron, J.-P.: An interactive vegetation SVAT model tested against data from six contrast ing sites, Agr. Forest Meteorol., 92, 73-95, 1998.

Calvet, J.-C.: Investigating soil and atmospheric plant water stress using physiological and micrometeorological data sets, Agr. Forest Meteorol., 103, 229-247, 2000.

Calvet, J.-C. and Soussana, J.-F.: Modelling $\mathrm{CO}_{2}$-enrichment effects using an interactive vegetation SVAT scheme, Agr. Forest Meteorol., 108, 129-152, 2001.

Calvet, J.-C., Rivalland, V., Picon-Cochard, C., and Guehl, J.-M.: Modelling forest transpiration and $\mathrm{CO}_{2}$ fluxes - response to soil moisture stress, Agr. Forest Meteorol., 124(3-4), 143-156, doi:10.1016/j.agrformet.2004.01.007, 2004.

Calvet, J.-C., Gibelin, A.-L., Roujean, J.-L., Martin, E., Le Moigne, P., Douville, H., and Noilhan, J.: Past and future scenarios of the effect of carbon dioxide on plant growth and transpiration for three vegetation types of southwestern France, Atmos. Chem. Phys., 8, 397-406, 2008, http://www.atmos-chem-phys.net/8/397/2008/.

Chen, J. M., Menges, C. H., and Leblanc, S. G.: Global mapping of foliage clumping index using multi-angular satellite data, Remote Sens. Environ., 97(4), 447-457, doi:10.1016/j.rse.2005.05.003, 2005.

Ciais, P., Viovy, N., Reichstein, M., Ogée, J., Granier, A., Knohl, A., Rambal, S., Sanz, M.-J., Schulze, D., Chevallier, F., and Valentini, R.: An Unprecedented Reduction in Primary Productivity of Europe During the Summer Heatwave in 2003, Nature, 437, 529-533, doi:10.1038/nature.03972, 2005.
Collatz, G. J., Ball, J. T., Grivet, C., and Berry, J. A.: Physiological and environmental regulation of stomatal conductance, Agr. Forest Meteorol., 54, 561-570, 1991.

Courtier, P., Freydier, C., Geleyn, J.-F., Rabier, F., and Rochas, M.: The Arpège project at Météo-France, Proc. ECMWF Seminar on Numerical Methods in Atmospheric Models, ECMWF, Reading, UK, 2, 193-232, 1991.

De Rosnay, P., Calvet, J.-C., Kerr, Y., Wigneron, J.-P., Lemaître, F., Escorihuela, M. J., Sabater, J. M., Saleh, K., Barrie, J., Coret, L., Cherel, G., Dedieu G., Durbe, R., Fritz, N., Froissard, F., Kruszewski, A., Lavenu, F., Suquia, D., and Waldteufel, P.: SMOSREX: A long term field campaign experiment for soil moisture and land surface processes remote sensing, Remote Sens. Environ., 102, 377-389, 2006.

Dickinson, R. E., Henderson-Sellers, A., Rosenzweig, C., and Sellers, P. J.: Evapotranspiration models with canopy resistance for use in climate models: A review, Agr. Forest Meteorol., 54, 373 388, 1991.

Dolman, H., Noilhan, J., Durand, P., Sarrat, C., Brut, A., Piguet, B., Butet, A., Jarosz, N., Brunet, Y., Loustau, D., Lamaud, E., Tolk, L., Ronda, R., Miglietta, F., Gioli, B., Magliulo, V., Esposito, M., Gerbig, C., Körner, S., Galdemard, P., Ramonet, M., Ciais, P., Neininger, B., Hutjes, R., Elbers, J. A., Warnecke, T., PérezLanda, G., Sanz, M. J., Scholz, Y., Facon, G., Ceschia, E., and Beziat, P.: CERES, the CarboEurope Regional Experiment Strategy in Les Landes, South West France, May-June 2005, B. Am. Meteorol. Soc., 87(10), 1367-1379, doi:10.1175/BAMS-87-101367, 2006.

Durand, Y., Brun, E., Merindol, L., Guyomarc'h, G., Lesaffre, B., and Martin, E.: A meteorological estimation of relevant parameters for snow models, Ann. Glaciol., 18, 65-71, 1993.

Durand, Y., Giraud, G., Brun, E., Merindol, L., and Martin, E.: A computer-based system simulating snow-pack structures as a tool for regional avalanche forecasting, Ann. Glaciol., 45, 469-484, 1999.

Foley, J. A., Prentice, I. C., Ramunkutty, N., Levis, S., Pollard, D., Sitch, S., and Haxeltine, A.: An integrated biosphere model of land surface processes, terrestrial carbon balance en vegetation dynamics, Global Biogeochem. Cy., 10, 603-628, 1996.

Garratt, J. R.: Sensitivity of climate simulations to land-surface and atmospheric boundary layer treatments: a review, J. Climate, 6 , 419-449, 1993.

Garrigues, S., Lacaze, R., Baret, F., Morisette, J. T., Weiss, M., Nickeson, J., Fernandes, R., Plummer, S., Shabanov, N. V., Myneni, R., and Yang, W.: Validation and intercomparison of global leaf area index products derived from remote sensing data, J. Geophys. Res., 113, G02028, doi:10.1029/2007JG000635, 2008.

Gibelin, A.-L., Calvet, J.-C., Roujean, J.-L., Jarlan, L., and Los, S. O.: Ability of the land surface model ISBA-A-gs to simulate leaf area index at the global scale: Comparison with satellites products, J. Geophys. Res., 111(D18), D18102, doi:10.1029/2005JD006691, 2006.

Gilmanov, T. G., Soussana, J.-F., Aires, L., Allard , V., Ammann, C., Balzarolo, M., Barcza, Z., Bernhofer, C., Campbell, C. L., Cernusca, A., Cescatti, A., Clifton-Brown, J., Dirks, B. O. M., Dore, S., Eugster, W., Fuhrer, J., Gimeno, C., Gruenwald, T., Haszpra, L., Hensen, A., Ibrom, A., Jacobs, A. F. G., Jones, M. B., Lanigan, G., Laurila, T., Lohila, A., Manca, G., Marcolla, B., Nagy, Z., Pilegaard, K., Pinter, K., Pio, C., Raschi, 
A., Rogiers, N., Sanz, M. J., Stefani, P., Sutton, M., Tuba, Z., Valentini, R., Williams, M. L., and Wohlfahrt, G.: Partitioning European grassland net ecosystem $\mathrm{CO}_{2}$ exchange into gross primary productivity and ecosystem respiration using light response function analysis, Agr. Ecosyst. Environ., 121, 93-120, doi:10.1016/j.agee.2006.12.008, 2007.

Heymann, Y., Steenmans, C., Croisille, G., Bossard, M., Lenco, M., Wyatt, B., Weber, J.-L., O’Brian, C., Cornaert, M.-H., and Sifakis, N.: CORINE Land Cover Technical Guide, Environment, nuclear safety and civil protection series, Commission of the European Communities, Office for Official Publications of the European Communities, Luxembourg, EUR 12585, ISBN 92-826-2578-8, 144 pp., 1993.

Jacobs, C. M. J., van den Hurk, B. J. J. M., and de Bruin, H. A. R.: Stomatal behavior and photosynthesis rate of unstressed grapevines in semi-arid conditions, Agr. Forest Meteorol., 80, 111-134, 1996.

Jarosz, N., Béziat, P., Bonnefond, J. M., Brunet, Y., Calvet, J. C., Ceschia, E., Elbers, J. A., Hutjes, R. W. A., and Traullé, O.: Effect of land use on carbon dioxide, water vapour and energy exchange over terrestrial ecosystems in Southwestern France during the CERES campaign, Biogeosciences Discuss., 6, 27552784, 2009,

http://www.biogeosciences-discuss.net/6/2755/2009/.

Jin, Y., Schaaf, C. B., Woodcock, C. E., Gao, F., Li, X., Strahler, A. H., Lucht, W., and Liang,S.: Consistency of MODIS surface BRDF/Albedo retrievals: 1. Algorithm performance, J. Geophys. Res., 108(D5), 4158, doi:10.1029/2002JD002803, 2003.

Kanemasu, E. T., Heilman, J. L., Bagley, J. O., and Powers, W. L.: Using Landsat data to estimate evapotranspiration of winter wheat, NASA Technical Report, Environmental Management, 1(6), 515-520, NASA-supported research, 1977.

Krinner, G., Viovy, N., de Noblet-Ducoudré, N., Ogée, J., Polcher, J., Friedlingstein, P., Ciais, P., Sitch, S., and Prentice, I. C.: A dynamic global vegetation model for studies of the coupled atmosphere-biosphere system, Global Biogeochem. Cy., 19, GB1015, doi:10.1029/2003GB002199, 2005.

Lacaze, R., Chen, J. M., Roujean, J. L., and Leblanc, S. G.: Retrieval of vegetation clumping index using hotspot signatures measured by the POLDER instrument, Remote Sens. Environ, 79, 84-95, 2002.

Martin, E., Le Moigne, P., Masson, V., Boone, A., Bogatchev, A., Brut, A., Bouyssel, F., Calvet, J.-C., Champeaux, J.L., Chancibault, K., Decharme, B., Donier, S., Douville, H., Dziedzic, A., Giard, D., Faroux, S., Fischer, C., Gibelin, A.L., Habets, F., Hello, G., Jarlan, L., Jidane, M., Kraljevic, L., Kullmann, L., Lac, C., Lacarrère, P., Lebeaupin, C., Mahfouf, J.M., Malardel, S., Mallet, I., Marquet, P., Masson, V., Mokthari, M., Payart, J., Noilhan, J., Quintana-Seguí, P., Seity, Y., Tulet, P., Vincendon, B., Zaaboul, R., and Zuurendonk, I.: Le code de surface externalisé SURFEX de Météo-France, Ateliers de Modélisation de l'Atmosphère, Toulouse, 16-18 January, 2007.

Masson, V., Champeaux, J.-L., Chauvin, F., Meriguet, C., and Lacaze, R.: A global database of land surface parameters at 1-km resolution in meteorological and climate models, J. Climate, 16, 1261-1282, 2003.

Nicholls, M. E., Denning, A. S., Prihodko, L., Vidale, P.-L., Baker, I., Davis, K., and Bakwin, P.: A multiple-scale simulation of variations in atmospheric carbon dioxide using a cou- pled biosphere-atmospheric model, J. Geophys. Res., 109(D18), D18117, doi:10.1029/2003JD004482, 2004.

Noilhan, J. and Planton, S.: A simple parameterization of land surface processes for meteorological models, Mon. Weather Rev., 117, 536-549, 1989.

Noilhan, J. and Mahfouf, J.-F.: The ISBA land surface parameterisation scheme, Global Planet. Change, 13, 145-159, 1996.

Pitman, A. J.: The evolution of, and revolution in, land surface schemes designed for climate models, Int. J. Climatol., 23, 479_ 510, 2003.

Pontailler, J.-Y., Hymus, G. J., and Drake, B. G.: Estimation of leaf area index using ground based remote sensed NDVI measurements: validation and comparison with two indirect techniques, Can. J. Remote Sens., 29(3), 381-387, 2003.

Postel: Pôle d'Observation des Surfaces continentales par Télédétection, Toulouse, France, online available at: http:// postel.mediasfrance.org/en/, last access: August 2009, 2008

Quintana-Segui, P., Le Moigne, P., Durand, Y., Martin, E., Habets, F., Baillon, M., Canellas, C., Franchisteguy, L., and Morel, S.: Analysis of near surface atmospheric variables: Validation of the SAFRAN analysis over France, J. Appl. Meteorol. Clim., 47, 92 107, 2008.

Ritter, B. and Geleyn, J.-F.: A comprehensive radiation scheme of numerical weather prediction with potential application to climate simulations, Mon. Weather Rev., 120, 303-325, 1992.

Rivalland, V., Calvet, J.-Ch., Berbigier, P., Brunet, Y., and Granier, A.: Transpiration and CO-2 fluxes of a pine forest: modelling the undergrowth effect, Ann. Geophys., 23, 291-304, 2005, http://www.ann-geophys.net/23/291/2005/.

Roujean, J.-L. and Lacaze, R.: Global mapping of vegetation parameters from POLDER multiangular measurements for studies of surface-atmosphere interactions: A pragmatic method and its validation, J. Geophys. Res., 107(D12), 4150, doi:10.1029/2001JD000751, 2002.

Sabater, J. M., Jarlan, L., Calvet, J.-C., Bouyssel, F., and De Rosnay, P.: From near-surface to root-zone soil moisture using different assimilation techniques, J. Hydrometeorol., 8(2), 194-206, doi:10.1175/JHM571.1, 2007.

Sabater, J. M., Rüdiger, C., Calvet, J.-C., Jarlan, L., and Kerr, Y.: Joint assimilation of surface soil moisture and LAI observations into a land surface model, Agr. Forest Meteorol., 148(8-9), 1362-1373, doi:10.1016/j.agrformet.2008.04.003, 2008.

Sarrat, C., Noilhan, J., Lacarrére, P., Ceschia, E., Ciais, P., Dolman, A. J., Elbers, J. A., Gerbig, C., Gioli, B., Lauvaux, T., Miglietta, F., Neininger, B., Ramonet, M., Vellinga, O., and Bonnefond, J. M.: Mesoscale modelling of the $\mathrm{CO}_{2}$ interactions between the surface and the atmosphere applied to the April 2007 CERES field experiment, Biogeosciences, 6, 633-646, 2009, http://www.biogeosciences.net/6/633/2009/.

Sellers, P. J., Randall, D. A., Collatz, G. J., Berry, J. A., Field, C. B., Dazlich, D. A., Zhang, C., Collelo, G. D., and Bounoua, L.: A revised land surface parameterization $(\mathrm{SiB} 2)$ for atmospheric GCMs, Part I : Model Formulation, J. Climate, 9, 676-705, 1996.

Shukla, J. and Mintz, Y.: The Influence of Land-Surface Evapotranspiration on the Earth's Climate, Science, 214, 1498-1501, 1982.

Tian, Y., Zhang, Y., Knyazikhin, Y., Myneni, R. B., and Running, S. W.: Prototyping of MODIS LAI/FPAR algorithm with LASUR and Landsat data, IEEE T. Geosci. Remote, 38(5), 2387-2401, 
2000.

Van den Hurk, B. J. J. M., Viterbo, P., and Los, S. O.: Impact of leaf area index seasonality on the annual land surface evaporation in a global circulation model, J. Geophys. Res., 108, D64191, doi:10.1029/2002JD002846, 2003.

Verhoef, W.: Earth observation modeling based on layer scattering matrices, Remote Sens. Environ., 17, 165-178, 1985.

Vuichard, N., Soussana, J.-F., Ciais, P., Viovy, N., Ammann, C., Calanca, P., Clifton-Brown, J., Fuhrer, J., Jones, M., and Martin, C.: Estimating the greenhouse gas fluxes of European grasslands with a process-based model: 1. Model evaluation from in situ measurements, Global Biogeochem. Cy., 21, GB1004, doi:10.1029/2005GB002611, 2007.
Weiss, M., Baret, F., Garrigues, S., and Lacaze, R.: LAI and fAPAR CYCLOPES global products derived from VEGETATION. Part 2: validation and comparison with MODIS collection 4 products, Remote Sens. Environ., 110(3), 317-331, 2007.

White, M. A., Thornton, P. E., and Running, S. W.: A continental phenology model for monitoring vegetation responses to interannual climatic variability, Global Biogeochem. Cy., 11, 217-234, 1997.

Zeng, N. and Neelin, J. D.: The role of vegetation-climate interaction and interannual variability in shaping the African Savanna, J. Climate, 13, 2665-2670, 2000. 